\title{
Long-term follow-up of percutaneous peripheral interventions in lower limb arteries in patients with acute coronary syndrome and diabetes
}

\author{
Wyniki odległe przezskórnych interwencji obwodowych w zakresie tętnic kończyn dolnych \\ u chorych z ostrym zespołem wieńcowym i wspólistniejącą cukrzycą
}

\section{Stanisław Bartuś, Zbigniew Siudak, Michał Chyrchel, Tomasz Rakowski, Artur Dziewierz, Michał Brzeziński, Jacek Skowronek, Beata Bobrowska, Marcin Suska, Jacek S. Dubiel, Dariusz Dudek}

Department of Interventional Cardiology, Jagiellonian University Medical College, Krakow, Poland

Post Kardiol Interw 2010; 6, 3 (21): 117-121 DOI: $10.5114 /$ pwki.2010.16352

\begin{abstract}
Background: Diabetes mellitus is a quite frequent comorbidity among patients with acute coronary syndromes (ACS). The presence of diabetes has also predicted poor outcome after lower limb percutaneous transluminal angioplasty (PTA).

Aim: To determine outcomes of patients with and without diabetes mellitus treated with PCI and PTA at index hospital stay during a 12-month follow-up.

Material and methods: There were 116 NSTACS (non ST elevation acute coronary syndromes) patients gathered in this prospective registry study in 2003-2009 in one academic center in Krakow, Poland.

Results: Data on consecutive patients who underwent PTA and PCI procedure during the same hospital stay were analyzed. Of these, 16 (14\%) had diabetes mellitus, the other 100 (86\%) had no history of diabetes. Both groups differed significantly with regard to gender and past medical history. During one-year observation $12.5 \%$ patients died in diabetes group vs. $2 \%$ in non-diabetes group $(p=0.033)$. Diabetes mellitus has turned out to be a strong predictor of outcome measured by the occurrence of repeated percutaneous peripheral procedure in 12-month observation.

Conclusions: Patients with diabetes mellitus have more aggravating past medical history with more frequently coexisting comorbidities. Diabetes mellitus in patients with ACS treated by PCI and PTA is associated with impaired 1-year survival. Diabetes itself is a strong predictor of repeated PTA procedures.
\end{abstract}

Key words: peripheral angioplasty, diabetes, acute coronary syndrome, limb ischaemia

\section{Streszczenie}

Wstęp: Współwystępowanie cukrzycy i ostrych zespołów wieńcowych (OZW) jest częstym zjawiskiem. Obecność cukrzycy jest predyktorem niekorzystnego rokowania chorych po zabiegach przezskórnej angioplastyki tętnic kończyn dolnych (ang. percutaneous transluminal angioplasty, PTA).

Cel: Porównanie bezpośrednich wyników leczenia chorych z cukrzycą i bez cukrzycy metodą przezskórnej interwencji wieńcowej (ang. percutaneous coronary intervention, PCI) oraz PTA w czasie tej samej hospitalizacji oraz określenie wyników leczenia w 12-miesięcznej obserwacji.

Materiał i metody: Stu szesnastu chorych z OZW bez uniesienia odcinka ST zostało włączonych do prospektywnego rejestru w czasie badania w latach 2003-2009 w jednym centrum akademickim w Krakowie.

Wyniki: Analizowano dane chorych, którzy przebyli procedury PCI i PTA w czasie jednego pobytu szpitalnego. Spośród tych chorych 16 (14\%) miało rozpoznaną cukrzycę, pozostali nie byli leczeni z tego powodu [100 (86\%)]. Obie grupy różniły się istotnie statystycznie ze względu na płeć i wywiad. W ciągu rocznej obserwacji 12,5\% osób zmarło w grupie chorych na cukrzycę w przeciwieństwie do $2 \%$ zgonów w grupie chorych bez cukrzycy $(p=0,033)$. Cukrzyca okazała się również silnym czynnikiem konieczności wykonania ponownych interwencji przezskórnych w ciągu 12-miesięcznej obserwacji.

Adres do korespondencji/Corresponding author:

Stanisław Bartuś MD, PhD, II Klinika Kardiologii, Szpital Uniwersytecki, ul. Kopernika 17, 31-501 Kraków, tel.: +48 1242471 81,

e-mail: mbbartus@cyf-kr.edu.pl

Praca wpłynęła 24.08.2010, wersja poprawiona wpłynęła 30.08.2010, przyjęta do druku 30.08.2010. 
Wnioski: Pacjenci z cukrzycą mieli bardziej obciążający wywiad chorobowy z licznymi chorobami towarzyszącymi. Obecność cukrzycy u chorych z OZW leczonych metodą PCI i PTA jest związana z istotnie pogorszonym przeżyciem w 12-miesięcznej obserwacji. Cukrzyca jest ponadto silnym predyktorem konieczności ponownych rewaskularyzacji przezskórnych.

Słowa kluczowe: interwencje obwodowe, cukrzyca, ostry zespół wieńcowy, niedokrwienie kończyn dolnych

\section{Introduction}

Diabetes mellitus is a quite frequent comorbidity among patients with acute coronary syndromes (ACS) [1-3]. It is also an established predictor of impaired inhospital and long-term outcome in ACS patients treated with percutaneous coronary interventions $(\mathrm{PCI})[2,4]$. Some studies suggest that glycaemia itself rather than past medical history of diabetes is a better and stronger determinant of survival $[5,6]$.

Diabetic patients are at high risk for peripheral arterial disease [7]. It is quite common that the atherosclerosis coexists in many arterial beds - in coronary artery disease patients in up to $30 \%$ of the cases. The presence of diabetes has also predicted poor outcome after lower limb percutaneous transluminal angioplasty (PTA) [8]. There are still insufficient data concerning long-term clinical outcome for patients with diabetes treated with PTA, especially in the setting of ACS.

The aim of this registry study was to determine outcomes of patients with and without diabetes treated with PCl and PTA during index hospital stay during a 12month follow-up.

\section{Material and methods}

Patients with the diagnosis of non-ST elevation acute coronary syndrome (NSTE ACS) treated with percutaneous coronary intervention $(\mathrm{PCl})$ and PTA during the same hospital stay were enrolled in this registry study in 2003-2009. PTA was performed only in patients with critical lesions in lower limb arteries confirmed in angiography and in patients with the duration of clinical symptoms of limb ischaemia of at least 3 months (intermittent claudication). Study conduct and patient enrollment was performed according to the Declaration of Helsinki and general GCP rules. Detailed study rationale and methods have been previously published [9-11].

Patients were divided into two groups: patients with diabetes mellitus (DM+) and those without diabetes (DM-). The diagnosis of diabetes mellitus was based upon past medical history, patient documentation and/or intake of oral hypoglicaemic agents or insulin.

Study primary efficacy endpoint was the occurrence of major adverse cardiac and cerebrovascular event (MACCE) in 12-month follow-up. Major adverse ischaemic events (MACCE) were defined as the occurrence of death, repeated myocardial infarction, urgent coronary revascularization ( $\mathrm{PCl}$ or $\mathrm{CABG}$ ) or ischeaemic stroke/transient ischaemic attack (TIA).
Secondary endpoint was defined as the occurrence of MAPE (Major Adverse Peripheral Event) during a 12-month observation (repeated PTA, ischaemic stroke/TIA or amputation due to limb ischaemia or its complications).

In-hospital bleeding complications were defined as the occurrence of major bleeding requiring blood transfusion.

Clinical long-term follow-up was performed in the $12^{\text {th }}$ month after index procedures by a dedicated physician with ultrasonography and ankle-brachial index (ABI) assessment. Telephone contact was advised only in cases in which the patient was unable to attend the visit at the out-patient department.

Registry data were analyzed according to the accepted standards of descriptive statistics. Categorical data were compared using $\chi^{2}$ and Fisher exact tests. These data were presented as percentages. Continuous data were presented as means \pm standard deviation and compared between the groups using two-sided U Mann-Whitney test. Event free survival curves were plotted by Kaplan-Meier estimator with long-rank test to search for differences between patients with and without diabetes mellitus. A logistic regression model for independent predictors of rePTA was built. Predictors which were significant $(p<0.1)$ in univariate analysis were included in multivariate analysis. A $p$ value of $<0.05$ was considered statistically significant. All calculations were performed using STATISTICA 8.0 software (Statsoft Inc., Tulsa, OK., USA).

\section{Results}

Data on 116 consecutive patients who underwent PTA and $\mathrm{PCl}$ procedure during the same hospital stay were analyzed. Of these, 16 (14\%) had diabetes mellitus, the other 100 (86\%) had no history of diabetes. Both groups differed significantly with regard to gender and past medical history (tab. 1). No differences were observed though in the clinical magnitude of lower limb ischemia as measured by Fontaine scale and claudication distance.

Details concerning the character and location of atherosclerotic disease in lower limb arteries as well as result of the PTA procedures are depicted in table 2 . A median time from $\mathrm{PCl}$ to PTA procedure (the same hospital stay) was similar between the groups (DM+ vs. DM-: $4.1 \pm 1.5$ vs. $4.0 \pm 1.7$ days, $p=N S)$. One patient in DM+ group $(6.25 \%)$ and five patients in DM-group (5\%) had PTA procedure immediately following $\mathrm{PCI}$.

During one-year observation $12.5 \%$ patients died in diabetes group vs. $2 \%$ in non-diabetes group $(p=0.033)$. 
Table 1. Demographic data and medical history Tabela 1. Dane demograficzne i wywiad chorobowy pacjentów

\begin{tabular}{lccc} 
& DM+ & DM- & $p$ \\
\hline Gender (males) [\%] & 63 & 84 & $0.042^{*}$ \\
\hline Age [years] & $63.4 \pm 7.8$ & $61.8 \pm 9.3$ & 0.357 \\
\hline BMI [kg/m²] & $26.5 \pm 3.2$ & $25.9 \pm 3.1$ & 0.652 \\
\hline Prior angina [\%] & 100 & 49 & $<0.001^{*}$ \\
\hline Previous MI [\%] & 69 & 36 & $0.013^{*}$ \\
\hline Hypertension [\%] & 100 & 50 & $<0.001^{*}$ \\
\hline Hypercholesterolaemia [\%] & 94 & 42 & $<0.001^{*}$ \\
\hline Current smoker [\%] & 50 & 28 & 0.077 \\
\hline Prior stroke / TIA [\%] & 38 & 5 & $<0.001^{*}$ \\
\hline Fontaine scale [\%] & & & \\
1 & 0 & 9 & 0.822 \\
2a & 17 & 19 & \\
2b & 83 & 69 & \\
3 & 0 & 3 & \\
\hline Claudication distance [meters] & $92 \pm 79$ & $118 \pm 169$ & 0.852
\end{tabular}

DM - diabetes mellitus, BMI - body mass index, TIA - transient ischaemic attack, $\mathrm{MI}$ - myocardial infarction

DM - cukrzyca, BMI - indeks masy ciała, TIA - przejściowy atak niedokrwienny, $\mathrm{Ml}$ - zawat serca

Other ischaemic events occurred similarly in both study groups in long-term follow-up (tab. 3).

In order to reduce selection bias typical for registries multivariate regression analysis was performed to determine independent predictors of repeated PTA procedure due to restenosis. Diabetes mellitus has turned out to be among others a strong predictor of outcome measured by repeated percutaneous peripheral procedure in 12-month follow-up (tab. 4).

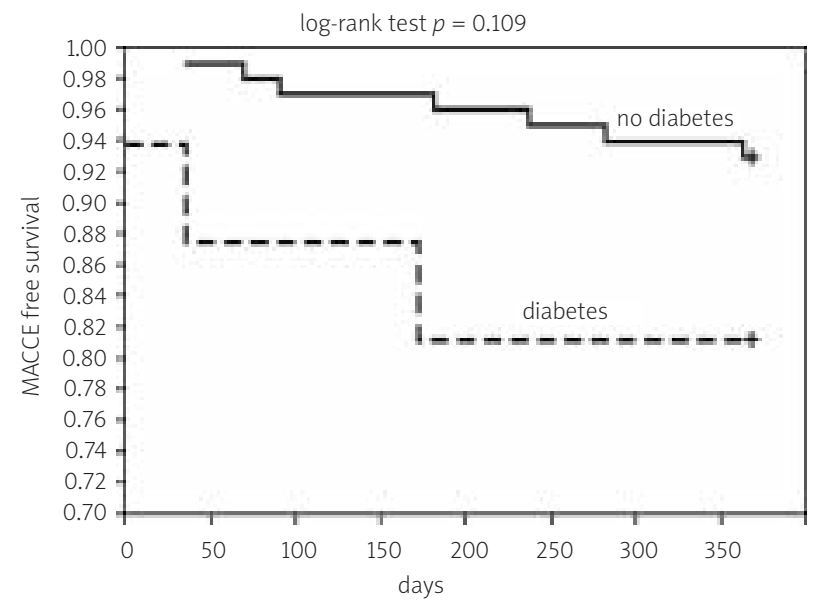

Fig. 1. MACCE free survival in 1-year follow-up by Kaplan-Meier

MACCE - major adverse cerebrovascular and cardiac events

Ryc. 1. Krzywa Kaplana-Meiera 1-rocznego przeżycia chorych wolnego od MACCE

MACCE - główne mózgowo-naczyniowe i sercowe zdarzenia niepożadane
Table 2. Angiography and percutaneous transluminal angioplasty data

Tabela 2. Dane dotyczace badania angiograficznego i zabiegu PTA

\begin{tabular}{lccc} 
& DM+ & DM- & $p$ \\
\hline Artery [\%] & & & \\
Common iliac & 19 & 43 & 0.073 \\
Superficial femoral & 81 & 51 & \\
Femoral & 0 & 6 & \\
\hline Stenting during PTA [\%] & 62 & 38 & 0.072 \\
\hline Satisfactory PTA result [\%] & 86 & 85 & 0.912
\end{tabular}

DM - diabetes mellitus, PTA - percutaneous transluminal angioplasty DM - cukrzyca, PTA - angioplastyka przezskórna

Moreover, figures 1 and 2 depict Kaplan-Meier event free survival curves for MACCE and MAPE respectively in both study groups (DM+ and DM-). No significant differences have been shown.

\section{Discussion}

The main cause of PAD is the process of forming atherosclerotic plaques. Risk factors which promote plaque formation include smoking habit, diabetes, hypercholesterolemia, hypertension and hyperhomocysteinaemia.

The occurrence of PAD in general population varies from 3 to $10 \%$ with the rise in elderly patients to up to $25 \%$ [15]. It is also worth noticing that CAD often coexists with PAD in almost as much as $30 \%$ of cases. Jeremias et al. revealed that PAD coexisted in $5.9 \%$ of patients with acute myocardial infarction treated by $\mathrm{PCI}$ [12]. Even after adjusting for the baseline and procedural characteristics, $P A D$ remained an independent predictor of in-hospital

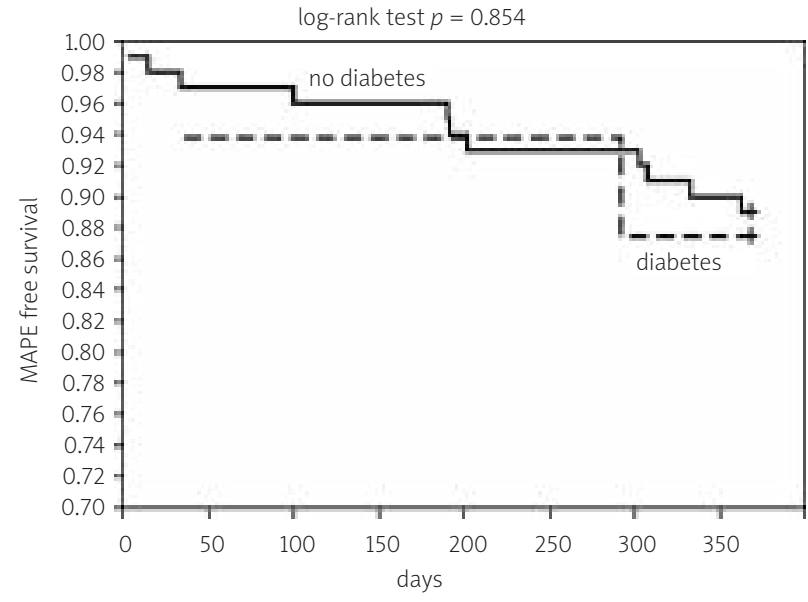

Fig. 2. MAPE free survival in 1-year follow-up by Kaplan-Meier MAPE - major adverse peripheral events

Ryc. 2. Krzywa Kaplana-Meiera 1-rocznego przeżycia chorych wolnego od MAPE

MAPE - gtówne zdarzenia niepożądane dotyczące naczyń obwodowych 
Table 3. Results of 12-month clinical follow-up Tabela 3. Wyniki 12-miesięcznych obserwacji klinicznych

\begin{tabular}{lccc} 
& $\begin{array}{c}\text { DM+ } \\
n=16\end{array}$ & $\begin{array}{c}\text { DM- } \\
n=100\end{array}$ & $p$ \\
\hline Death [\%] & 12.5 & 2 & $0.033^{*}$ \\
\hline $\begin{array}{l}\text { Myocardial infarction } \\
\text { (STEMI + NSTEMI) [\%] }\end{array}$ & 0 & 2 & 0.568 \\
\hline Stroke / TIA [\%] & 6.3 & 2 & 0.320 \\
\hline PCI [\%] & 6.3 & 3 & 0.508 \\
\hline rePTA [\%] & 6.3 & 9 & 0.716 \\
\hline $\begin{array}{l}\text { Elective PTA of arteries other than } \\
\text { index ones [\%] }\end{array}$ & 0 & 5 & 0.361 \\
\hline $\begin{array}{l}\text { Lower limb amputation [\%] } \\
\text { Death + myocardial infarction [\%] }\end{array}$ & 12.5 & 4 & 0.154 \\
\hline $\begin{array}{l}\text { Death + myocardial infarction } \\
+ \text { stroke/TIA + urgent coronary } \\
\text { revascularization (MACCE) [\%] }\end{array}$ & 18.8 & 7 & 0.119 \\
\hline $\begin{array}{l}\text { rePTA + stroke/TIA + amputation } \\
\text { (MAPE) [\%] }\end{array}$ & 12.5 & 11 & 0.859 \\
\hline $\begin{array}{l}\text { In-hospital bleeding complications [\%] } \\
\text { (M) }\end{array}$ & & 0 & - \\
\hline
\end{tabular}

DM - diabetes mellitus, STEMI - ST elevation myocardial infarction, NSTEMI - non-ST elevation myocardial infarction, TIA - transient ischaemic attack, PTA - percutaneous transluminal angioplasty, MACCE - major adverse cerebrovascular and cardiac events, MAPE - major adverse peripheral events

DM - cukrzyca, STEMI - zawat serca z uniesieniem odcinka ST, NSTEMI - zawat serca bez uniesienia odcinka ST, TIA - przejściowy atak niedokrwienny, PTA - angioplastyka przezskórna, MACCE - główne mózgowo-naczyniowe i sercowe zdarzenia niepożądane, MAPE główne zdarzenia niepożadane dotyczace naczyn obwodowych

mortality in this study (odds ratio $2.2,95 \%$ confidence interval 1.7 to $3.0, p<0.001$ ). In the REACH registry 1 -year mortality was $12.6 \%$ in patients with atherosclerosis in one arterial bed and $26.3 \%$ in those with atherosclerosis in three beds [13]. Multilevel atherosclerosis requires thus additional attention since it significantly impairs clinical outcome.

Duran et al. found out that arterial hypertension and diabetes were independent predictors of multilevel atherosclerotic disease [14]. Moreover, the frequency of adverse clinical events was significantly higher in patients with PAD $(20.4 \%$ vs. $7.0 \%, p<0.001)$ as well as mortality in long-term follow-up (13\% vs. 3.8\%, $p<0.001)$.

The diagnosis, predisposing factors and treatment of PAD are described in the current TASC II guidelines. Compared with the original TASC guidelines more emphasis has been put on the association of diabetes and PAD [16]. Multiple studies have shown an association between diabetes mellitus and the development of PAD. Intermittent claudication is about twice as common in diabetic patients. Additional evidence suggest that insulin resistance plays a major role in a clustering of cardiometabolic risk factors like hyperglycemia, dyslipidemia,
Table 4. Multivariate regression analysis model for independent predictors of repeated PTA

Tabela 4. Wieloczynnikowa analiza regresji dla niezależnych czynników ryzyka powtórnej PTA

\begin{tabular}{|c|c|c|c|}
\hline & OR & $95 \% \mathrm{Cl}$ & $p$ \\
\hline $\begin{array}{l}\text { Unsatisfactory result of PTA } \\
\text { procedure (suboptimal, dissection, } \\
\text { residual narrowing) }\end{array}$ & 3.04 & $1.41-4.95$ & 0.011 \\
\hline Hypercholesterolaemia & 1.33 & $1.10-1.61$ & 0.041 \\
\hline Diabetes mellitus & 2.52 & $1.03-5.51$ & 0.045 \\
\hline $\begin{array}{l}\text { Multivessel disease in coronary } \\
\text { angiography }\end{array}$ & 2.06 & $1.45-2.61$ & 0.018 \\
\hline Current smoker & 2.05 & $1.01-3.56$ & 0.049 \\
\hline
\end{tabular}

obesity and hypertension. PAD in patients with diabetes is more aggressive in terms of outcome and complications compared to those without diabetes. Amputation rates are 5-10 times higher in diabetics. Based on many observations, a consensus statement from the American Diabetes Association recommends PAD screening with an $A B I$ every 5 years in patients with diabetes. Several studies revealed that aggressive lowering of glycaemia may prevent microvascular complications, however, this has not been demonstrated for PAD probably because the studies conducted so far examining glycemic control in diabetes were underpowered to study PAD endpoints.

There are very limited data concerning clinical outcome in patients with ACS treated by PCI which also present with clinically and angiographically significant PAD. Our registry study is one of the first to describe such patients [9-10]. In the current analysis we tried to predict outcome in diabetic patients which are known to have poor survival not only after coronary PCI procedures but also after PTA [8, 12].

As expected, patients with diabetes mellitus in our study turned out to be at higher risk due to co-existing comorbidities. But one must also take into account the relatively small number of patients enrolled. The only clinical parameter that was significant was 1-year death which was surely influenced by other factors. On the other hand, diabetes turned out to be an independent predictor of repeated PTA procedure which is also a marker of the progression of atheroscelrosis in general, also in the coronary bed.

Performing PTA and PCl procedures together (as in minority of our patients) or during one hospital stay (100\%) may be associated with additional exposure radiation and contrast volumes that may impair renal function. Although significantly larger amounts of contrast media and radiation were used for $\mathrm{PCl}$ (especially multivessel $\mathrm{PCI}$ ) than PTA, no substantial rise in contrast nephropathy was noticed in our registry population $[11,17]$.

The results of our study indicate that the presence of diabetes may impair the outcome of our coronary and 
peripheral procedures in terms of hard endpoints like death. It seems that adequate glicaemia control and statin therapy to control lipid levels and promote plaque stabilization is essential. Those factors were among others to independently predict restenosis. Finally, complete revascularization not only within the coronary tree is crucial for patients who require post ACS cardiac rehabilitation. Claudication and limb ischaemia may prevent those patients from proper secondary prevention. Adequate perfusion of lower limbs in diabetic patients could also prevent vascular complications of diabetes mellitus.

\section{Conclusions}

Patients with diabetes mellitus have more aggravating past medical history with more frequently coexisting comorbidities like previous MI, hypertension and stroke. Diabetes mellitus in patients with ACS treated by $\mathrm{PCl}$ and PTA is associated with impaired 1-year survival. However, no differences were found in combined study primary and secondary endpoints. Diabetes itself is a strong predictor of repeated PTA procedures.

\section{References}

1. Siudak Z, Dudek D, Kuta M, et al. Everyday treatment strategies of non ST-segment elevation acute coronary syndromes in hospitals without on-site invasive facility - The Malopolska Registry. Folia Cardiologica 2005; 12: 21-31.

2. De Luca G, Małek LA, Maciejewski P, et al. Impact of diabetes on survival in patients with ST-segment elevation myocardial infarction treated by primary angioplasty: insights from the POLISH STEMI registry. Atherosclerosis 2010; 210: 516-520.

3. Dudek D, Siudak Z, Kuta M, et al. Clinical characteristic and treatment strategy in patients with acute coronary syndromes in hospitals without on-site invasive facility. The Malopolska Registry of Acute Coronary Syndromes 2002-2003. Post Kardiol Interw 2005; 1, 2: 97-106.

4. Syed Al, Ben-Dor I, Li Y, et al. Outcomes in diabetic versus nondiabetic patients who present with acute myocardial infarction and are treated with drug-eluting stents. Am J Cardiol 2010; 105: 819-825.
5. Dziewierz A, Giszterowicz D, Siudak Z, et al. Admission glucose level and in-hospital outcomes in diabetic and non-diabetic patients with acute myocardial infarction. Clin Res Cardiol 2010 May 11. [Epub ahead of print]

6. Gąsior M, Stasiak-Pres G, Pres D, et al. Relationship between blond glucose on admission and prognosis in patients with acute myocardial infarction treated with percutaneus coronary intervention. Kardiol Pol 2007; 65: 1031-1038.

7. Jude EB, Eleftheriadou I, Tentolouris N. Peripheral arterial disease in diabetes - a review. Diabet Med 2010; 27: 4-14.

8. Abularrage CJ, Conrad MF, Hackney LA, et al. Long-term outcomes of diabetic patients undergoing endovascular infrainguinal interventions. J Vasc Surg 2010; 52: 314-322.

9. Bartuś S, Rakowski T, Siudak Z, et al. Recanalization of peripheral arteries by interventional cardiologists: rationale and results. Int J Cardiol 2008; 129: 304-306.

10. Bartuś S, Siudak Z, Brzeziński M, et al. Percutaneous peripheral interventions in patients with non-ST elevation acute coronary syndromes by interventional cardiologists: rationale and results. Kardiol Pol 2008; 66: 135-141.

11. Bartuś S, Siudak Z, Dziewierz A, et al. Comparison of hospital length of stay regarding the type of percutaneous intervention coronary vs. peripheral angioplasty. Kardiodiabetologia 2009; 4: 24-27.

12. Jeremias A, Gruberg L, Patel J, et al. Effect of peripheral arterial disease on in-hospital outcomes after primary percutaneous coronary intervention for acute myocardial infarction. Am J Cardiol 2010; 105: 1268-1271.

13. Steg PG, Bhatt DL, Wilson PW, et al; REACH Registry Investigators. One-year cardiovascular event rates in outpatients with atherothrombosis. JAMA 2007; 297: 1197-1206.

14. Duran NE, Duran I, Gürel E, et al. Coronary artery disease in patients with peripheral artery disease. Heart Lung 2010; 39 : 116-120.

15. Selvin E, Erlinger TP. Prevalence of and risk factors for peripheral arterial disease in the United States: results from the National Health and Nutrition Examination Survey, 1999-2000. Circulation 2004; 110: 738e-743e.

16. Norgren L, Hiatt WR, Dormandy JA, et al. Inter-Society Consensus for the Management of Peripheral Arterial Disease (TASC II). Eur J Vasc Endovasc Surg 2007; 33 (Suppl. 1): S1-75.

17. Bartuś S, Rakowski T, Siudak Z, et al. Comparison of the radiation dose regarding the type of percutaneous intervention coronary vs. peripheral angioplasty. Kardiodiabetologia 2009; 4: 28-30. 